Short Communication

\title{
Analgesic and antipyretic activity of methanolic extract of Leucas Clarki in animal models
}

\author{
Truptirekha Swain*, Rashmita Pradhan, Debasish Barik
}

Department of Pharmacology, S.C.B. Medical College,

Cuttack, Orissa, India

Received: 2 September 2013

Accepted: 14 September 2013

*Correspondence to:

Dr. Truptirekha Swain,

Email:

drtruptiswain@gmail.com

(C) 2013 Swain TR et al. This is an open-access article distributed under the terms of the Creative Commons Attribution Non-Commercial License, which permits unrestricted non-commercial use, distribution, and reproduction in any medium, provided the original work is properly cited.

\begin{abstract}
Background: Search for an indigenous safe and effective analgesic and antipyretic agent continues to be an exciting area of research. The objective of this study was to evaluate the analgesic and antipyretic activity of methanolic extract of Leucas clarki, in animal models.

Methods: Analgesic activity was evaluated in albino mice by acetic acid induced writhing test. Antipyretic study was carried out in albino rats by inducing pyrexia with brewer's yeast. Analgesic activity was expressed as percentage of reduction in number of writhings compared to vehicle (Tween-80) and antipyretic activity was expressed as reduction of rectal temperature compared to basal temperature, after 18 hours of induction of pyrexia. Leucas clarki extract was administered at 3 doses $(100,200,400 \mathrm{mg} / \mathrm{Kg})$ intraperitoneally. Student's paired and unpaired "t" test was applied to test significance.

Results: Methanolic extract of Leucas clarki (MLC) at dose $200 \mathrm{mg}$ and 400mg $/ \mathrm{kg}$ produced $19.17 \% \& 32.03 \%$ of reduction of no. of writhing induced by acetic acid compared to that of Tween 80 treated control mice, However this is less compared to aspirin treated control rats. In model of pyrexia all the three doses of MLC produced significant reduction of rectal temperature compared to basal temperature (18hrs). Antipyretic effect was appreciated at very first hour and persisted till the end of 6 hours like that of paracetamol. Both $100 \& 200$ $\mathrm{mg} / \mathrm{kg}$ MLC were equivalent in potency as that Paracetamol (33mg/kg I.P) and $400 \mathrm{mg} / \mathrm{kg}$ was even better than Paracetamol.
\end{abstract}

Conclusions: Methanolic extract of Leucas clarki possesses excellent antipyretic and analgesic property.

Keywords: Leucas Clarki, Analgesic activity, Antipyretic activity

\section{INTRODUCTION}

Pain and fever are two most common clinical symptoms which brings the patient to the clinician. Commonly prescribed analgesics and antipyretics when used for prolonged period, in chronic disorders like arthritis and spondylitis can produce serious side effects. ${ }^{1}$ Thus search for a safe and effective analgesic and anti pyretic continues to be an exciting area. Herbs have been the oldest remedies used by all cultures throughout history but India has one of the oldest, richest and diverse cultural living traditions associated with the use of medical plants. ${ }^{2}$ People all over the world are looking for the alternative system of medicines, which are claimed to be safe, equally effective and provide better answer to a chronic disease. Thus, to have an experimental base, the modern herbal medicines need to prove the scientific basis by reverse pharmacological approaches.
Lucas clarki is widely used among the tribal people of western Orissa for its antidiabetic and antipyretic activity. Leucas Lavendulofulia, a member of the family of Leucas $\mathrm{R}$ Brevis has already proved its beneficial effect on reducing blood sugar level and other properties. ${ }^{4}$ Our preliminary research on L. Clarki plant in this laboratory proved the beneficial effect of reducing blood sugar level in hyperglycemic rats. ${ }^{5}$ Thus it was felt to explore the possible analgesic and antipyretic property for which it is used by the tribal people without any scientific evidence.

The family of Lucas $\mathrm{R} . \mathrm{Br}$ has great medicinal potential particularly as antihistaminic antipyretic, antiseptic, carminative, febrifuge and wormifuge. They have also been found very effective in relieving anorexia, cough, dyspepsia, fever, helminths infestation, jaundice, psoriasis, and respiratory and skin disease. References about the medicinal uses of Lucas $\mathrm{R} . \mathrm{Br}$ species are available in ancient vedic literature (Sarmah, 1968-69). The drug 
obtained from these species of Lucas $\mathrm{R} . \mathrm{Br}$ in the trade is known as Drona or Dronapushpi which finds wide use in ayurvedic, homeopathic and unani systems of medicine. References about the medicinal uses of Leucas R.Br species are available in ancient Vedic literature (Sarmah 1968-69, 1971, 1972, 1973). All the species are being used in traditional systems of medicines as Dronapushpi. ${ }^{3}$ Thorough literature scan revealed that Leucas Clarki is also effective in curing anorexia, cough, dyspepsia, fever; helminths infestation, jaundice, psoriasis and respiratory and skin diseases. ${ }^{3}$ Thus, it was felt to explore the possible analgesic and antipyretic property of Leucas Clarki.

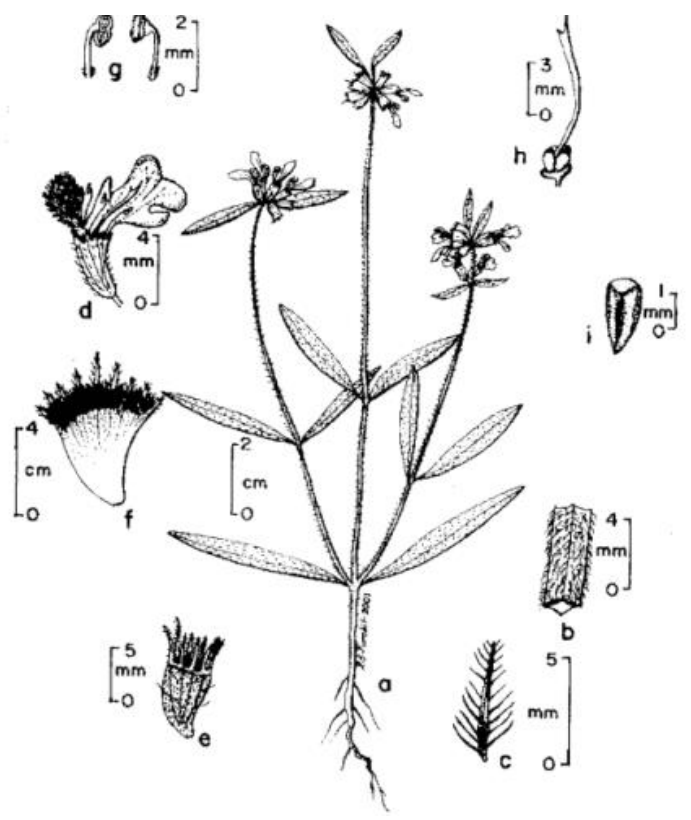

Figure 1: Leucas clarki a. habit, b. Portion of stem showing deflexed hairs, c. Bract, d. Flower, e. Calyx opened (inner view), g. Stamens, h. Gynoecium's, Nut let.

\section{METHODS}

Animals: Mice weighing between (25- $30 \mathrm{~g}$ ) and Wistar Albino rats of either sex weighing between 100-150 g were obtained from animal house, department of pharmacology. Animals were housed in PVC cages under standard condition (12:12 hour light/dark cycle at $25 \pm 2{ }^{\circ} \mathrm{C}$, humidity $\left.70-75 \%\right)$. The protocol was approved by Institutional Animal Ethics Committee of S.C.B Medical College, Cuttack.

Drugs: Methanolic extract of Leucas Clarki (MLC), standard drug Aspirin (Raw material from laboratory) and vehicle for MLC i.e. Tween80 constituted the material for screening analgesic effect by writhing test. MLC, standard drug Paracetamol (laboratory) constituted the material for anti-pyretic study. The test drug (Methanolic extract of Leucas Clarki) was obtained from Dept. of Pharmacology which was extracted and was preserved from previous anti diabetic study in the Department.

Methods: Writhing was induced in mice by injecting $0.6 \%$ acetic acid i.p. and pyrexia was induced in rats by injecting brewer's yeast. Writhing was counted for 30 min and analgesic activity was expressed as the percentage decrease in abdominal contractions (writhings). Antipyretic effect was observed in rats by injecting $20 \mathrm{ml} / \mathrm{kg}$ of $20 \%$ aqueous suspension of Brewer's yeast in normal saline subcutaneously below the nape of the neck. Rectal temperature was recorded 18 hrs after the injection of yeast. MLC at different doses $(100,200,400 \mathrm{mg} / \mathrm{kg})$ was tube fed orally. Mean rectal temperature was recorded at hourly interval till the end of $5 \mathrm{hr}$.

\section{RESULTS}

Analgesic Activity (Table-1): In acetic acid induced writhing test MLC, at doses $100 \mathrm{mg} / \mathrm{kg}$ did not produce any significant analgesic effect. However at dose of 200 and $400 \mathrm{mg} / \mathrm{kg}$, MLC produced significant analgesic effect as evidenced by reduction of no. of writhings in mice compared to vehicle, Tween 80 treated group of rats. But the analgesic potency was significantly less compared to standard drug aspirin suggesting analgesic potential of MLC less compared to aspirin.

Table 1: Effect of methanolic extract of Leucas Clarki on acetic acid induced writhing in mice.

\begin{tabular}{|c|c|c|c|}
\hline Drug & Dose (mg/kg) i.p. & $\begin{array}{l}\text { No. of writhings } \\
\text { (mean } \pm \text { SEM) }\end{array}$ & $\begin{array}{l}\% \text { Inhibition of } \\
\text { writhing }\end{array}$ \\
\hline Tween 80 (Control) & $0.5 \mathrm{ml}$ & $81.66 \pm 0.42$ & - \\
\hline MLC & 100 & $81 \pm 0.36$ & 0.81 \\
\hline MLC & 200 & $66 \pm 1.39 *^{\mathrm{a}}$ & 19.17 \\
\hline MLC & 400 & $55.5 \pm 1.58 *^{\mathrm{a}}$ & 32.03 \\
\hline Aspirin (Standard) & 100 & $29.5 \pm 0.43^{a}$ & 63.87 \\
\hline
\end{tabular}

Unpaired ' $\mathrm{t}$ ' test, $\mathrm{n}=6, \mathrm{df}=10, \mathrm{a}-\mathrm{p}<0.001$, when compared to Tween 80 (control) $* \mathrm{p}<0.001$, when compared to Aspirin. 
Table 2: Effect of Leucas Clarki on yeast induced pyrexia in rats.

\begin{tabular}{|c|c|c|c|c|c|c|c|c|}
\hline \multirow{3}{*}{ Drugs } & \multirow{3}{*}{$\begin{array}{l}\text { Dose } \\
\text { (mg/kg) } \\
\text { i.p. }\end{array}$} & \multicolumn{7}{|c|}{ Mean rectal temp. \pm S.E.M. in ${ }^{\circ} \mathrm{C}$ at } \\
\hline & & \multirow{2}{*}{ Basal } & \multirow{2}{*}{$\begin{array}{l}\text { After } 18 \\
\text { hrs. }\end{array}$} & \multicolumn{5}{|c|}{ Post - Drug } \\
\hline & & & & $1 \mathrm{hr}$. & $2 \mathrm{hrs}$. & $3 \mathrm{hrs}$. & 4 hrs. & $5 \mathrm{hrs}$. \\
\hline $\begin{array}{l}\text { Tween-80 } \\
\text { (control) }\end{array}$ & $0.5 \mathrm{ml}$ & $35.73 \pm 0.17$ & $\begin{array}{l}36.66 \pm 0.19 \\
( \pm 0.93)\end{array}$ & $\begin{array}{l}36.58 \pm \\
0.17\end{array}$ & $\begin{array}{l}36.55 \pm \\
0.18\end{array}$ & $\begin{array}{l}36.45 \pm \\
0.19\end{array}$ & $\begin{array}{l}36.48 \pm \\
0.18\end{array}$ & $\begin{array}{l}36.46 \pm 0.1 \\
7\end{array}$ \\
\hline MLC & 100 & $35.90 \pm 0.10$ & $\begin{array}{l}36.76 \pm 0.08 \\
( \pm 0.86)\end{array}$ & $\begin{array}{l}36.53 * \pm 0 \\
.04\end{array}$ & $\begin{array}{l}36.34 * \pm 0 \\
.08\end{array}$ & $\begin{array}{l}36.21 * \pm 0.1 \\
1\end{array}$ & $\begin{array}{l}36.15 * \pm 0.1 \\
0\end{array}$ & $\begin{array}{l}36.00 \pm 0 . * \\
10\end{array}$ \\
\hline MLC & 200 & $35.85 \pm 0.13$ & $\begin{array}{l}36.68 \pm 0.17 \\
( \pm 0.83)\end{array}$ & $\begin{array}{l}36.46^{* * \pm} \pm \\
0.17\end{array}$ & $\begin{array}{l}36.15^{* * \pm} \\
0.15\end{array}$ & $\begin{array}{l}36.05 * * \pm 0 \\
13\end{array}$ & $\begin{array}{l}36.00 * * \pm 0 \\
12\end{array}$ & $\begin{array}{l}35.90 \pm 0 . * \\
* 13\end{array}$ \\
\hline MLC & 400 & $35.18 \pm 0.13$ & $\begin{array}{l}36.25 \pm{ }^{\mathrm{a}} 0.09 \\
( \pm 1.07)\end{array}$ & $\begin{array}{l}36.00^{\mathrm{a}} \pm 0 . \\
09 * * *\end{array}$ & $\begin{array}{l}35.61^{\mathrm{a}} \pm \\
0.13^{* * *}\end{array}$ & $\begin{array}{l}35.45^{\mathrm{a}} \pm \\
0.12^{* * *}\end{array}$ & $\begin{array}{l}35.34^{\mathrm{a}} \pm \\
0.12^{* * *}\end{array}$ & $\begin{array}{l}35.18 \pm 0 .^{\mathrm{a}} \\
13 * * *\end{array}$ \\
\hline $\begin{array}{l}\text { Paracetam } \\
\text { ol }\end{array}$ & 33 & $36.15 \pm 0.13$ & $\begin{array}{l}36.93 \pm 0.19 \\
( \pm 0.78)\end{array}$ & $\begin{array}{l}36.51 \pm \\
0.19\end{array}$ & $\begin{array}{l}36.28 \pm \\
0.17\end{array}$ & $\begin{array}{l}36.16 \pm \\
0.18\end{array}$ & $\begin{array}{l}36.10 \\
\pm 0.19\end{array}$ & $\begin{array}{l}36.10 \pm \\
0.19\end{array}$ \\
\hline
\end{tabular}

Values within parenthesis - change in temperature following yeast injection. Paired' $t$ ' test, $n=6, d f=5{ }^{*} p<0.05$ when compared with $18 \mathrm{hr}$ value, ${ }^{* * *} \mathrm{p}<0.001$, when compared to rectal temp $18 \mathrm{hr}$ value. ${ }^{\mathrm{a}} \mathrm{p}<0.001$ when compared to rectal temperature of Paracetamol treated rats.

Table 2, demonstrates antipyretic activity of Leucas clarki. In contrast to analgesic activity, antipyretic activity of MLC was observed at all three doses (100, $200,400 \mathrm{mg} / \mathrm{kg}$ ) and this effect was even better than paracetamol, the standard antipyretic at dose of was found out to be $33 \mathrm{mg} / \mathrm{kg}$.

\section{DISCUSSION}

Animals are used since time immemorial to screen pharmacological action of different compounds. Since our purpose was primarily to screen the analgesic activity of Leucas clarki, we selected a single model of chemical induced pain with $1 \mathrm{ml} / \mathrm{Kg}$ of body weight of $6 \%$ acetic acid in mice. ${ }^{6}$ Writhing model of pain generally corroborates with peripheral analgesic activity of test compound. ${ }^{7}$ Though MLC only at the dose of 200 and $400 \mathrm{mg} / \mathrm{kg}$ showed distinct analgesic action when compared to tween- 80 treated control rats, this action was significantly less compared to Aspirin. This suggests a comparative weak analgesic action of MLC compared to standard analgesics. Thus this drug can only be used as an add on drug to conventional analgesic. A number of studies have probed for possible analgesic effect in plants. $^{8,9}$ On the contrary, MLC at doses 100, 200, $400 \mathrm{mg} / \mathrm{kg}$ produced, significant antipyretic effect. The onset of antipyretic activity was appreciated at the very first hour, which is similar to that of paracetamol. At 400 $\mathrm{mg} / \mathrm{Kg}$ dose the effect was significantly high from both MLC (100 and $200 \mathrm{mg} / \mathrm{Kg}$ ) and paracetamol, but at this high dose there may be some toxic potential.

Normally different NSAIDs are used either alone or in combination to treat fever and analgesia. These two disorders are often coexistent and prostaglandins are responsible for the pathological process. MLC at all the doses showed significant antipyretic activity and it has weak analgesic effect. This type of behaviour is observed with standard antipyretic drug paracetamol. At the dose of $400 \mathrm{mg} / \mathrm{Kg}$ of MLC, though the antipyretic action was most observed, safety status is unproven. Essential oils constituents such as (-) linalool antagonize different pain responses elicited by exposure to a chemical stimulant as acetic induced by thermal stimuli or by tissue injury. ${ }^{10} \mathrm{R}$ Suekewa et al showed analgesic and antipyretic properties from ginger extract in a large number of laboratory animals. ${ }^{11}$ This plant contains monoterpenes and trioterpenes ${ }^{5}$ as principal compounds. This suggests the analgesic and antipyretic effect probably due to the essential oil constituents. Further studies are required to elucidate in detail, the analgesic and antipyretic property along with toxic profile\& mechanism of action of this versatile plant.

\section{CONCLUSION}

Thus methanolic extract of Leucas clarki possess significant antipyretic property at all three doses. But it has weak analgesic activity which can be used as a possible addition to any established analgesic agent. Further study is needed to establish the active principle responsible for both analgesic and antipyretic property.

\section{ACKNOWLEDGEMENTS}

We are thankful to Indian council of medical research for providing funding for this project. 
Funding: Indian Council of Medical Research (ICMR) Conflict of interest: None declared

Ethical approval: The study protocol was approved by Institutional Animal Ethics Committee of S.C.B. Medical College, Cuttack

\section{REFERENCES}

1. Unwanted effects and adverse drug reactions, in Clinical Pharmacology, Bennett \& Brown, 9th Edition, Page 139-140.

2. V. Tandor, B. Kapoor. Herbal drug research in India: A trend analgesic using IJP as a marker (1995-2003). Indian J Pharmacol 2004;6:99-100.

3. Monograph on Indian Lucas R. Br.(Dronapushpi) Lamiaceae by V.Singh; Scientific Publishers (India), Jodhpur, ISBN: 81- 7233-286-6.

4. Kakalisaha, Pulak k. Mukharjee, J. Das, Subasch. Das, Manal M. Hypoglycemic activity of Lucas lavandilofulia Rees in streptozotocin induced diabetic rats. Phytotherapy Research;6:373-376.

5. S. Sahu, Swain TR, A. Shree, S.N Pandeya. Different phytochemical analysis and antidiabetic activity of leucas clarki. Dissertation submitted to the BijuPattanaik university of technology (BPUT) in partial fulfilment for the award of the degree of masters of pharmacy in pharmaceutical chemistry.

6. Some common techniques. Screening of analgesic activity of different compound, Fundamentals of experimental pharmacology, M.N. Ghosh: 3rd edition. page 176.

7. Loux JJ, Depalma PD, Yarkell SL. Antipyretic testing of aspirin in rats. Toxicol Appl Pharmcol 1972;22:6725 .

8. Hossinzadeh H, Ramezini M, Fadishei M. Antinociceptive, anti inflammatory and acute toxicity effects of Zhumeriamajdac extracts in mice and rats. Phytomediam 2002;9:135-41.

9. M. Bishnoi, C.S. Patil, A. Kunal et al. Analgesic activity of acetyl-11-Keta-beta-boswellic acid, a 5lipoxygense inhibitor. Indian J Pharmacol. 2005;37:4.

10. Anti inflammatory and antinociceptive activaties of Zingiberofficinale roscoe Essential oil in experimental animal models. Indian J Pharmacol 2006;38:58-59.

11. Suekawa M, Ishige A, Yuasa K. Pharmacological studies on ginger. 1. Pharmacological actions of purgent constituents, (6)-gingerol and (6) shogaol. J Pharmacobiodyn 1984;7:836-48.

doi:10.5455/2319-2003.ijbcp20131230

Cite this article as: Swain TR, Pradhan R, Barik D.

Analgesic and antipyretic activity of methanolic extract of Leucas Clarki in animal models. Int J Basic Clin Pharmacol 2013;2:824-7. 